\title{
Is There Any Room for the Doctrine of Fundamental Rights of States in Today's International Law?
}

\author{
Daniel H Joyner* and Marco Roscini**
}

\begin{abstract}
This article serves as a general substantive introduction to the special issue on the fundamental rights of states in international law. It introduces the concept in theoretical and doctrinal terms, and lays out the questions that will be addressed by the contributions to the special issue. These questions include: 1) What do attributes like 'inherent', 'inalienable' and 'permanent' mean with regard to state rights?; 2) Do they lead to identifying a unitary distinct category of fundamental rights of states?; 3) If so, what is their source and legal character?; 4) What are their legal implications, eg, when they come into conflict with other obligations of the right holder or with the actions of other states and international organisations?; and ultimately, 5) Is there still room in today's international law for a doctrine of 'fundamental' rights of states? The article reviews the fundamental rights of states in positive law sources and in international legal scholarship, and identifies the reasons for a renaissance of attention for this doctrine.
\end{abstract}

\section{Keywords}

Fundamental Rights of States, International Law, Positivism, Natural Law, Kelsen

\section{Introductory remarks}

It is almost a truism to say that states have rights and duties under international law. Indeed, as Hans Kelsen emphasised, '[t]he State is an international personality because it is a subject of international duties and rights.' This also means that 'all the principles, norms and rules of International Law resolve themselves into the notion of rights and duties of States.' The question, however, is whether certain of these rights and duties are

* Professor of Law, University of Alabama (US).

** Professor of International Law, University of Westminster (UK).

1 Hans Kelsen, General Theory of Law and State (Anders Wedberg tr, The Law Book Exchange 2007) 250 (emphasis added).

2 Ricardo J Alfaro, 'The Rights and Duties of States' (1959) 97 Recueil des Cours 116. 
of a special, more fundamental character, in the same or similar way as certain rights of individuals allegedly are. ${ }^{3}$

The doctrine of fundamental rights of states is of venerable pedigree in international law and has undergone significant mutation and evolution over time with regard to understood theory, substance and function. Even though the function of the doctrine has changed throughout the centuries-having gone from guaranteeing the domestic jurisdiction of states and their freedom of action, to explaining the foundations of international law and its existence, to preserving the peaceful co-existence of states, and finally to the heterogeneous and diverse functions it presently plays ${ }^{4}$ - the concept still permeates present-day international law, if not in name, then in substance and implications. ${ }^{5}$

The starting point of our analysis is not natural law concepts or 'constitutional' approaches to international law, but rather the identification, in positivist sources, of certain state rights to which those sources attach special characteristics. Indeed, our interest in this topic originally grew out of our work, both individually and together, in the area of nuclear non-proliferation law. In particular, we have over the years found ourselves discussing in depth article IV(1) of the 1968 Treaty on the Non-proliferation of Nuclear Weapons (NPT), which recognises 'the inalienable right of all the Parties to the Treaty to develop research, production and use of nuclear energy for peaceful purposes. ${ }^{6}$ In the context of the NPT, article IV(1) is an important part of the 'Grand Bargain', which the NPT effectively codifies as between its nuclear weapon states parties and its non-nuclear weapon states parties.

In framing this recognition in article IV(1), the NPT drafters chose some rather unique language. All of the states parties to the NPT are recognised as possessing an 'inalienable right' to peaceful nuclear energy. This phraseology, which not only expresses this principle as a 'right' possessed by all states parties, but even further qualifies it as a right which is 'inalienable' in those states, has prompted us to consider deeply the meaning and implications of the idea of rights of states in international law, both in terms of this particular treaty provision, as well as in the broader context of the international legal system. Indeed, as will be seen, article IV(1) is by no means an isolated case.

This has prompted us to ask some important questions about the concept of the rights of states in international law, questions that have not been seriously addressed by legal scholarship in the last 55 years. What do attributes like 'inherent', 'inalienable' and 'permanent' mean with regard to state rights? Do they lead to identifying a unitary distinct category of fundamental rights of states? If so, what is their source and legal character? What are their legal implications, eg, when they come into conflict with

4

5 Helmut Philipp Aust, 'Fundamental Rights of States: Constitutional Law in Disguise?' (2015) 4 CJICL 521.

6 Treaty on the Non-proliferation of Nuclear Weapons (adopted 1 July 1968, entered into force 5 March 1970) 729 UNTS 161 (NPT) (emphasis added). 
other obligations of the right holder or with the actions of other states and international organisations? And, ultimately, is there still room in today's international law for a doctrine of 'fundamental' rights of states? Taking those questions into account, a number of observations can be made to properly identify the problem and the issues involved.

\section{The fundamental rights of states in positive sources}

One such observation is that the NPT is by no means the only place in the positive sources of international law in which certain rights of states appear to have a special character. The first legal instrument to attempt to address the subject in something of a systematic manner was the 1933 Montevideo Convention on the Rights and Duties of States, signed by 20 North and South American states, including the United States. ${ }^{7}$ The Montevideo Convention has come to be best known for its recitation in article I of the definition of a state and its necessary attributes. ${ }^{8}$ However, the Convention proceeds to identify certain rights possessed by every state, including in article III:

The right to defend its integrity and independence, to provide for its conservation and prosperity, and consequently to organize itself as it sees fit, to legislate upon its interests, administer its services, and to define the jurisdiction and competence of its courts.

Article III specifies that '[t]he exercise of these rights has no other limitation than the exercise of the rights of other states according to international law'. In article V, the parties to the Montevideo Convention further agree that ' $\mathrm{t}$ ] he fundamental rights of states are not susceptible of being affected in any manner whatsoever'.

Apart from the Montevideo Convention, the Charter of the Organization of American States (OAS), adopted in 1948, contains a whole chapter dedicated to the fundamental rights and duties of states. ${ }^{9}$ Recognitions of the rights of states in international law were also included in the Charter of the United Nations (UN Charter), drafted in $1945 .^{10}$ Notably, the UN Charter recognises a particular right of states in article 51, when it provides:

Nothing in the present Charter shall impair the inherent right of individual or collective selfdefence if an armed attack occurs against a Member of the United Nations, until the Security Council has taken measures necessary to maintain international peace and security.

7 Convention on Rights and Duties of States (adopted 26 December 1933, entered into force 26 December 1934) 165 LNTS 19 (Montevideo Convention).

8 Montevideo Convention, art I reads as follows: 'The state as a person of international law should possess the following qualifications: a) a permanent population; b) a defined territory; c) government; and d) capacity to enter into relations with the other states.'

9 Charter of the Organization of American States (adopted 30 April 1948, entered into force 13 December 1951) 119 UNTS 3.

10 Charter of the United Nations (adopted 26 June 1945, entered into force 24 October 1945) 1 UNTS XVI (UN Charter). 
As the right in article IV(1) of the NPT includes the adjective 'inalienable' in its description, so article 51 of the UN Charter includes the different, yet equally potentially meaningful, adjective 'inherent' in its description in English ('droit naturel' in French). The significance of this qualification, however, has been too quickly dismissed in the literature. $^{11}$

In addition to the recognition of states' rights in legally binding instruments, the International Law Commission (ILC) grappled with this subject and in 1949 adopted a draft Declaration on Rights and Duties of States, consisting of 14 draft articles which enunciated, in broad terms, some of the basic rights and duties of states. ${ }^{12}$ In his history of the work of the ILC, Sir Arthur Watts commented as follows regarding the draft declaration:

As international law developed in the second half of the nineteenth century and the first half of the twentieth it was thought useful, and perhaps even necessary, to consider whether there were some fundamental legal principles which were inherent in the relations of States as members of the international community. The search for some hierarchical structure to the many particular rules of international law seemed to require no less. The idea grew that there were certain fundamental rights which were essential and self-evident attributes of Statehood, together with certain fundamental duties. This notion was particularly prevalent in the Americas, and manifested itself [in a number of delineated treaties and statements]. Although the general concept was generally accepted, there was no general agreement as to which particular rights and duties fell into this 'fundamental' category. ${ }^{13}$

The draft Declaration adopted by the ILC in answer to this need for a general agreement includes a list of ten duties and four basic rights of states, similarly broadly defined. ${ }^{14}$ The ILC transmitted its draft Declaration to the UN General Assembly, where for two years it was considered and commented on by states. However, no further official action was ever taken on the Declaration, and it has remained unadopted by the UN General Assembly. Sir Arthur Watts had the following to say about the failure of the draft Declaration to be adopted by the UN General Assembly:

In part this seems to have been due to the inherent problems of this sort of Declaration, drafted as they inevitably are (and as the Commission thought fitting) in very broad, general terms. (...) There were, however, more important factors at work. One was the beginnings of the rapid increase in the number of members of the United Nations, which changed the

11 See, eg, Albrecht Randelzhofer and Georg Nolte, 'Article 51' in Bruno Simma and others (eds), The Charter of the United Nations: A Commentary (3rd edn, OUP 2012) vol II. But see Marco Roscini, 'On the "Inherent" Character of the Right of States to Self-Defence' (2015) 4 CJICL 634.

12 Kelsen was highly critical of the ILC draft Declaration. See Hans Kelsen, 'The Draft Declaration on Rights and Duties of States: Critical Remarks' (1950) 44 AJIL 259.

13 ILC, 'Report of the International Law Commission on the Work of its 51st Session' (3 May-23 July 1999) UN Doc A/54/10, 1645.

14 Draft Declaration on Rights and Duties of States with Commentaries (1949) Ybk Intl L Com 287-90. See Kelsen, 'The Draft Declaration' (n 12) 265: 'the principles of international law which the Declaration of Rights and Duties of States intends to formulate could-and should-be formulated only in terms of duties. (...) For the duty is the primary, the right a secondary, legal concept'. 
whole social dynamic relevant to any determination of the rights and duties which should be regarded as 'fundamental' to the position of States within the international community. A second was the emergence into the forefront of international relations of the communistcapitalist ideological conflict, which again undermined the relevance of the essentially older conceptions of fundamental rights and duties of States which pervaded the outcome of the work done by the Commission. ${ }^{15}$

While the dynamic nature of politics during that time may have made adoption of the draft Declaration impossible, the two phenomena to which Watts refers-the newly independent states created primarily by decolonisation through the 1950-60s and the influence of communism during that period-were not in fact antithetical per se to the concept of the fundamental rights of states in international law. Quite the opposite in fact. Scholars writing in socialist theory and scholars from newly independent states during these decades strongly supported the core concepts of state sovereignty and the existence of certain basic rights of states in international law. ${ }^{16}$

Once somewhat settled, these two forces together were instrumental in the inclusion of article IV in the NPT in 1968-referenced earlier-and in the successful adoption by the General Assembly of a number of resolutions recognising rights of states in international law. ${ }^{17}$ The first of these resolutions, which Watts describes as the 'modern successor' to the idea of the fundamental rights and duties of states, ${ }^{18}$ was Resolution 2625, adopted in 1970 and entitled 'Declaration on Principles of International Law concerning Friendly Relations and Co-operation among States'. Although primarily expressing the duties of states, the Declaration on Friendly Relations also recognised the following principles, which hearken back to the Montevideo Convention's delineation of states' rights (note again the use of the adjective 'inalienable' in relation to the third right):

No State may use or encourage the use of economic, political or any other type of measures to coerce another State in order to obtain from it the subordination of the exercise of its sovereign rights and to secure from it advantages of any kind. Also, no State shall organize, assist, foment, finance, incite or tolerate subversive, terrorist or armed activities directed towards the violent overthrow of the regime of another State, or interfere in civil strife in another State.

The use of force to deprive peoples of their national identity constitutes a violation of their inalienable rights and of the principle of non-intervention.

Every State has an inalienable right to choose its political, economic, social and cultural systems, without interference in any form by another State. ${ }^{19}$

15 ILC (n 13) 1646.

16 See Malcolm Shaw, International Law (7th edn, CUP 2014) 23-25; Stephen C Neff, 'A Short History of International Law' in Malcom Evans (ed), International Law (3rd edn, OUP 2010) 23.

17 See Daniel H Joyner, Interpreting the Nuclear Nonproliferation Treaty (OUP 2011) 17-20.

18 ILC (n 13) 1646.

19 Declaration on Principles of International Law concerning Friendly Relations and Co-operation among States (adopted 24 October 1970) UNGA Res 2625 (XXV). 
Similarly, but addressing a theme made particularly relevant during the 1970s, when nationalisations of foreign oil and other investments occurred with increased frequency in the developing world, in 1973 the General Assembly adopted Resolution 3171, in which it 'reaffirm[ed] the inalienable rights of States to permanent sovereignty over all their natural resources. ${ }^{20}$ A more systematic and thorough statement of states' rights in the area of economic development and international trade was given by the General Assembly a year later in Resolution 3281, entitled 'Charter of Economic Rights and Duties of States.' ${ }^{21}$ This resolution, an outgrowth of the New International Economic Order programme for revising the post Second World War economic system and institutions in favour of developing states, relied heavily on the language of the fundamental rights of states in its provisions and laid out these rights in some detail. The 1981 adoption by the General Assembly of Resolution 36/103 provided a similar assertion of states' rights on the question of the inadmissibility of intervention and interference in the internal affairs of states.

The existence of certain fundamental rules and inherent rights of states was also implied during this period in judgments of the International Court of Justice (ICJ). In the North Sea Continental Shelf judgment, for instance, the Court held that:

The doctrine of the just and equitable share appears to be wholly at variance with what the Court entertains no doubt is the most fundamental of all the rules of law relating to the continental shelf, enshrined in Article 2 of the 1958 Geneva Convention, though quite independent of it, namely that the rights of the coastal State in respect of the area of continental shelf that constitutes a natural prolongation of its land territory into and under the sea exist ipso facto and $a b$ initio, by virtue of its sovereignty over the land, and as an extension of it in an exercise of sovereign rights for the purpose of exploring the seabed and exploiting its natural resources. In short, there is here an inherent right. In order to exercise it, no special legal process has to be gone through, nor have any special legal acts to be performed. Its existence can be declared (and many States have done this) but does not need to be constituted. Furthermore, the right does not depend on its being exercised. To echo the language of the Geneva Convention, it is 'exclusive' in the sense that if the coastal State does not choose to explore or exploit the areas of shelf appertaining to it, that is its own affair, but no one else may do so without its express consent. ${ }^{22}$

In the same case, the Court also referred to rules 'having an a priori character of so to speak juristic inevitability, ${ }^{23}$ although it denied that the equidistance principle was one of those rules. ${ }^{24}$

20 Permanent Sovereignty over Natural Resources (adopted 17 December 1973) UNGA Res 3171 (XXVIII) (emphasis added).

21 Charter of Economic Rights and Duties of States (adopted 12 December 1974) UNGA Res 3281 (XXIX).

22 North Sea Continental Shelf (Germany v Denmark; Germany v The Netherlands) (Judgment) [1969] ICJ Rep 3 , para 19.

23 ibid para 37.

24 ibid para 46. 
In the Gulf of Maine judgment, the ICJ found that:

A body of detailed rules is not to be looked for in customary international law which in fact comprises a limited set of norms for ensuring the co-existence and vital co-operation of the members of the international community, together with a set of customary rules whose presence in the opinio juris of States can be tested by induction based on the analysis of a sufficiently extensive and convincing practice, and not by deduction from preconceived ideas. $^{25}$

The Court, therefore, distinguished between two types of customary rules: 'regular' ones, and the more 'limited set of norms', which are necessary for the co-existence and co-operation within the international community and whose existence is not based on induction from opinio juris and state practice. ${ }^{26}$

Finally, in the Nuclear Weapons Advisory Opinion, the ICJ referred to the 'fundamental right of every State to survival' as the ultimate foundation of the right of self-defence. ${ }^{27}$ One possible reading of the Court's conclusions is that, while the right of self-defence in 'ordinary' circumstances may be founded on and limited by positive law, its exercise in extreme circumstances where the very survival of the state is at stake rests on other more fundamental grounds that escape regulation by positive law.

\section{Rights of states in international legal scholarship}

While a number of authors in this special issue will at a much greater depth address the subject of the history of the concept of the rights of states in international law, as well as international legal scholarship on this topic, ${ }^{28}$ we would make one further observation. There was, during the classical period of international legal scholarship (1648-1815) and before, a strong tradition of scholarly writing regarding the fundamental rights of states in international law, including in the works of Vitoria, Suarez, Grotius, Wolff and Vattel. ${ }^{29}$ Some of the richest scholarly debate on this topic emerged during the latter part of the nineteenth century and through the mid-twentieth century and was joined, among others, by such contemporary scholarly luminaries as Lassa Oppenheim, James Brierly, Charles de Visscher, Elihu Root, Arrigo Cavaglieri, Dionisio Anzilotti, Gilbert Gidel, Alphonse Rivier, Antoine Pillet and Hans Kelsen. If the classical doctrine of the fundamental rights of states saw them as deriving from natural law, scholars in the

25 Case Concerning Delimitation of the Maritime Boundary in the Gulf of Maine Area (Canada $v$ United States of America) (Judgment) [1984] ICJ Rep 246, para 111.

26 Martti Koskenniemi, From Apology to Utopia: The Structure of the International Legal Argument (CUP 2005) 406.

27 Legality of the Threat or Use of Nuclear Weapons (Advisory Opinion) [1996] ICJ Rep 226, paras 96-97, 105(E).

28 d'Aspremont (n 4); Stephen C Neff, 'The Dormancy, Rise and Decline of Fundamental Liberties of States' (2015) 4 CJICL 482.

29 Alfaro (n 2) 116-30. 
nineteenth and twentieth centuries relied on 'logical, historical, sociological or even positive bases. ${ }^{30}$ Otherwise said, they saw the fundamental rights of states as resulting from the very existence and operation of the international society, and not as superior to it. ${ }^{31}$

Ricardo Alfaro provided an in-depth treatment of the subject in his Hague Academy of International Law course in 1959, which appears in the Recueil des Cours of that year. ${ }^{32}$ His 1959 monograph deserves, in our opinion, to be considered the seminal modern work on the subject of the fundamental rights of states in international law, and appears to constitute the last focused and thorough scholarly treatment of the subject until the present day. Drawing upon his exhaustive review and discussion of literature and legal theory, Alfaro constructs a practical theory and taxonomy of the rights of states in international law. In particular, he identifies two categories of state rights. The first category of state rights, according to Alfaro, consists of subsidiary, or acquired, rights. These rights are obtained by states through the sources of the jus dispositivum, and particularly through customary international law or treaty law. ${ }^{33}$

The second category consists of fundamental rights, which in his view are not created by states, but simply exist because states exist-they are 'a direct emanation of the State itself. ${ }^{34}$ In his own words,

Do fundamental rights of the State exist?, asks Le Fur. (...) My answer (...) is unhesitatingly in the affirmative, for I find myself unable to conceive a State divested of the four rights of independence, sovereignty, equality and self-preservation, or any one of them. Whether called attributes, qualities, competencies, powers, norms or rights, the conclusion seems inescapable that these are the fundamental rights of every State, from which emanate all the other rights that have been variously called subjective, eventual, secondary, accessory and, most aptly, acquired, since they have been acquired by customs or by treaty. ${ }^{35}$

30 Emmanuelle Jouannet, The Liberal-Welfarist Law of Nations: A History of International Law (CUP 2014) 125.

31 ibid 126.

32 See Alfaro (n 2) 95-117. See also Kelsen, 'The Draft Declaration' (n 12) 259-76; Martti Koskenniemi, The Gentle Civilizer of Nations (CUP 2004) 238-45, 281-83; Elihu Root, 'The Declaration of the Rights and Duties of Nations Adopted by the American Institute of International Law' (1916) 10 AJIL 211; James L Brierly, The Law of Nations: An Introduction to the International Law of Peace (Sir Humphrey Waldcock ed, 6th edn, Clarendon Press 1963) 50; Philip M Brown, 'The Rights of States under International Law' (1916) 26 Yale LJ 85; Charles de Visscher, Theory and Reality in Public International Law (Percy E Corbett tr, Princeton UP 1968) 16.

33 Alfaro (n 2) 104.

34 ibid 109.

35 ibid 104 (emphasis in original). Also, at 112:

Sovereignty implies the duty of every State to respect the rights emanating from it, pursuant to international law. Independence imposes on all States the basic duty of nonintervention. Equality creates an obligation for each State to render to every other State on equal terms that which is due to them by reason of their International Personality; and to recognize and accept from each of them all such lawful acts as are equal to those performed by all member of the Family of Nations. Selfpreservation rests upon the reciprocal duty of every State not to injure, impair or destroy the integrity of any State nor to violate any of its legal rights. 
Several points stand out from Alfaro's analysis. The first is the identification of 'four essential attributes inherent in and inseparable from the conception of the State, namely: sovereignty, independence, equality and self-preservation, ${ }^{36}$ and the recognition that all other legal rights of states emanate from these four fundamental rights and are typically acquired by states through the jus dispositivum sources of treaty and custom. Alfaro's is therefore a hierarchical system of legal rights grouped into two categories: fundamental and acquired, with acquired rights being grounded in, and subsidiary to, fundamental rights.

The second point emerging from Alfaro's treatment is the identification of legal obligations which necessarily accompany both fundamental and acquired legal rights. Accordingly, a state's possession of a legal right creates in all other states-and one would assume an extension to other actors with more limited international legal personality (ie international organisations) - a corresponding obligation to respect that right, and not to interfere with, or act to prejudice it.

Thirdly, the distinction in the source from which the rights flow has a clear impact on Alfaro's understanding and theory of the nature and implications of those rights. Since fundamental rights are those without which the state would not be a state, Alfaro argues that they are not only inherent, but also inviolable and inalienable. ${ }^{37}$ When identifying subsidiary or acquired rights, however, he is clear that these rights are produced through jus dispositivum sources. They would thus appear to be non-inherent, subject to modification or even consensual relinquishment, and subject also to the application of interpretive canons when there is conflict between these acquired rights and either obligations of the rights holder or obligations of other states.

One of Alfaro's principles on which Hans Kelsen was in agreement is the principle that all rights of states in international law create obligations of respect for those rights in other states, and by extension in international organisations. Kelsen explains this principle in more theoretical depth:

It is usual to distinguish between a right to one's own behavior and a right to the behavior of another. To say that a (physical or juristic) person has a right to behave in a certain way may mean only that there is no duty of this person to behave in another way. This, however, implies that all the other persons have the duty to refrain from preventing the subject of the 'right' to behave in this way. The right to one's own behavior is always the right to the behavior of others. But we speak of a right that a person has to the behavior of another in a specific sense of the term if a definite other person has the duty to behave in a certain way in relation to the subject of the right. A person has a right to the behavior of another person only if the other person has the duty to behave in this way. Finally, the term 'right' is used in its narrowest, technical sense if it designates the legal power conferred upon a person to bring about, by an action brought before a court, the execution of a sanction provided by the law in case another person violates his obligation to behave in a certain way in relation to 
the subject of the right. Hence, the right of one person always presupposes the corresponding duty of another person. In the first two cases mentioned the legal situation is completely described by a statement referring to the duty. The right of the one is but the reflection of the duty of another. Under general international law, only rights in this sense exist, since general international law does not institute courts. (...) The rights of states under general international law are always the reflection of the duties imposed by general international law upon other states. ${ }^{38}$

Kelsen, however, adamantly opposed any naturalistic notion of the existence of fundamental rights possessed by states, insisting rather that rights could only be obtained by a state through the positivistic sources of the jus dispositivum, and in particular through customary international law. Kelsen was also not convinced by the alleged link between the fundamental rights of states and the notion of statehood. He chaffed against an overly anthropomorphic view of the state as a unitary actor and holder of both rights and duties. As he explains:

The so-called fundamental rights and duties of the States are rights and duties of the States only in so far as they are stipulated by general international law, which has the character of customary international law. Such rights have been chiefly enumerated as the right of existence, the right of self-preservation, the right of equality, the right of independence, the right of territorial and personal supremacy, the right of intercourse, the right of good name and reputation, and the right of jurisdiction. (...) However, 'international personality of the State' means only that general international law imposes duties and confers rights upon States (and that means upon individuals as organs of the States). ${ }^{39}$

Alfaro, however, is by no means the first or only scholar to see certain rights of states as inherent in statehood. ${ }^{40}$ In fact, the vast majority of scholars of the period 1850-1945, which saw the rise and triumph of positivism, linked the doctrine of fundamental rights of states to the notion of statehood. ${ }^{41}$ Woolsey, for instance, argues that such rights are 'those necessary for the conception of states, and for their occupying the sphere which the Author of society has marked out for them. ${ }^{42}$ Oppenheim writes that 'under the wrong heading of fundamental rights a good many correct statements have been made for hundreds of years, and (...) numerous real rights and duties are customarily recognised which are derived from the very membership of the Family of Nations. ${ }^{43}$ Gidel also maintains that the fundamental rights of states are:

des droits qui appartiennent à tout État du fait de son existence même, qui sont inhérents à lui et qui présentent le triple caractère dêtre absolus, inviolables, inaliénables. Ils sont absolus

38 Kelsen, 'The Draft Declaration' (n 12) 264.

39 Kelsen, General Theory (n 1) 249-50.

40 See the references in Alfaro (n 2) 106-08.

41 d'Aspremont (n 4).

42 Theodore D Woolsey, Introduction to the Study of International Law (5th edn, Charles Soribner \& Co 1879) 35.

43 Lassa Oppenheim, International Law: A Treatise (3rd edn, Longmans, Green and Co 1920) vol I, 194. 
en ce sense que l'État perdrait ses caractères distinctifs s'ils venaient à manquer et cesserait d'être une 'personne du droit international. ${ }^{44}$

These views were implicitly upheld by the ILC with its choice to adopt a Declaration on rights and duties of states, and not a convention, as 'the rights and duties of States as such are not created by the text of a treaty or international Convention but are inherent in their quality as States and can only be recognized or stated. ${ }^{45}$

In our opinion, it is important to emphasise that seeing certain rights as a corollary of statehood does not necessarily imply a fall back upon natural law, as Kelsen argues: in fact, the opposite is true. ${ }^{46}$ Indeed, the definition and the elements of statehood itself are identified by positive law, ie in the above mentioned Montevideo Convention and its customary counterpart. Therefore, naturalistic views that see certain rights as primordial and pre-existent of states should be distinguished from more modern understandings that see certain rights to be inherent in statehood as defined in positive law. As the notions of state, sovereignty, and even that of international law are the product of historical, political and other forces and are in a constant state of evolution and reconceptualisation, so concepts such as the rights of states that are of long pedigree may be refigured in our understanding of their origin, character and legal implication, to bring them into harmony with modern understandings of legal validity. ${ }^{47}$

\section{A needed renaissance of attention}

In spite of the above rich scholarly debate, for reasons that are not immediately apparent the subject of the fundamental rights of states in international law has all but disappeared from international legal scholarship over the past 55 years. This turn away from a focus on the rights of states may be explainable not only by present day's dominant opposition to natural law as a source of state rights, but also by the rise in emphasis over the same period upon the development of international human rights law and the right of selfdetermination of peoples, which some have perceived as, in at least some ways, at odds with conceptions of state rights. Whatever the reasons for this paucity of scholarship over the past half century, we are of the opinion that a number of the characteristics of the modern international legal system, and the present globalised international economic

44 Gilbert Gidel, 'Droits et Devoirs des Nations, la Théorie Classique des Droits Fondamentaux des Etats' (1925) 10 Recueil des Cours 541, 542.

45 UNGA, 'Preparatory Study Concerning a Draft Declaration on the Rights and Duties of States, Memorandum Submitted by the Secretary-General' (15 December 1948) UN Doc A/CN.4/2, 213.

46 Serge Sur, 'L’inhérence en Droit International' (2014) 118 Revue Générale de Droit International Public $785,786$.

47 ibid 795. A similar reconceptualisation of an ancient principle of international law has taken place in our evolved understanding of the concept of customary international law. See Stephen Hall, 'The Persistent Spectre: Natural Law, International Order and the Limits of Legal Positivism' (2001) 12 EJIL 269. 
environment, make a renaissance of scholarly attention to the issue of states' rights in international law advisable.

The international legal system has undergone a tremendous and unprecedented substantive and institutional evolution since the end of the Second World War. International legal sources have both broadened in their scope and deepened in their content and application to state behaviour, in ways that were previously unimagined. The rise to prominence in role of international organisations as fora not only for coordination of state action, but also for law-making, monitoring and verification of state conduct, and in some cases adjudication of legal disputes, has made the international legal system a very different, much more complex place than it once was for states, who were once the only and independent actors within it. ${ }^{48}$

This modern structure of the international legal system, in which the legal obligations of states are often made, monitored, adjudicated and enforced through international organisations, has taken on post-Westphalian aspects of constitutionalism and maturity as a legal system that have changed significantly the position of states. Indeed, a number of scholars have recently recognised international organisations as agents in which a decay in the traditional paradigm of state consent in international law-making has taken place. $^{49}$

As the international legal system matures, grows increasingly complex, dense and fragmented, and moves towards a more complete legal system, it would appear to be manifestly sensible and necessary for states, and particularly developing and less powerful states, to have clearly developed understandings not only of their obligations within that legal system, but also of their rights, which can potentially be used as a shield against excessive encroachment upon their sovereign independence by other more powerful actors. $^{50}$

In particular, the UN Security Council is one of the most legally influential of these international organisations (or, in its specific case, one organ of an international organisation). The UN Charter provides in article 25 for the authority of the Security Council to take decisions that are legally binding on all UN member states. The Council's understanding of its role and powers, and the question of the legal limits of those powers under the Charter, is a subject that has been widely debated by international

48 See, eg, Dan Sarooshi, International Organizations and their Exercise of Sovereign Powers (OUP 2007).

49 See Nico Krisch, 'The Decay of Consent: International Law in an Age of Global Public Goods' (2014) 108 AJIL 1; Laurence R Helfer, 'Nonconsensual International Lawmaking' (2008) 71 U Illinois L Rev 71; Andrew T Guzman, 'Against Consent' (2012) 52 Virginia J Intl L 747; Joel P Trachtman, The Future of International Law: Global Government (CUP 2013).

50 See Ulrich Preuss, 'Equality of States: Its Meaning in a Constitutionalized Global Order' (2008) 9 Chicago J Intl L 17, 46:

A further step in that direction would be the stipulation of a catalogue of fundamental rights of states which would especially protect small states against the disregard of their rights as distinct and constituent members of the international society. While some of these fundamental rights would be immune from any kind of balancing against common interests, others would be subject to balancing under the condition that high standards of justification would have to be met. 
legal scholars in recent years. ${ }^{51}$ In writing on this subject, one of the current authors has previously argued that the Security Council's understanding of its authority under the Charter has changed significantly since the end of the Cold War, to encompass not only its more traditional executive role in enforcing existing international law, but also an ascending legislative and adjudicatory role that has greatly expanded both the scope and substance of its decisions and has brought its actions into conflict with fundamental principles of international law. ${ }^{52}$

In light of the increased scope of action and self-understanding of authority of the UN Security Council in particular, all UN member states would appear to have a strong self-interest in developing and clarifying the concept of the rights of states in international law-in particular those which can be asserted against and which must be respected by other actors, including the Security Council. This is especially true for smaller and developing states, which are particularly susceptible to economic and financial sanctions imposed by the Security Council, as well as unilaterally by powerful states.

This susceptibility has been significantly amplified in recent decades due to the increased internationalisation of markets and interdependence of national economies, a phenomenon often referred to as globalisation. Globalisation has made developing states more vulnerable than ever before to both unilateral and collective sanctions imposed, and often coordinated between, powerful states, the most powerful of which sit as permanent members on the Security Council. For developing states, therefore, there would seem to be a particular modern imperative to balance the scales of this phenomenon through the development and clarification of, inter alia, a right to be free from economic coercion by other actors, which would in turn create in other states and international organisations an obligation to respect this right. ${ }^{53}$

\section{Structure and content of the special issue}

With this introduction to the special issue in place, we will proceed to describe the structure and content of the papers, and the themes/questions uniting them. The topic of the fundamental rights of states can be viewed from at least two different perspectives. One is an ontological consideration of the concept as it has evolved over time, and continues to evolve today. A second perspective is focused not on the broader themes of evolution and theory, but on the practical task of considering how provisions in positive legal sources which attach special characteristics (inherency, inalienability, permanency)

51 See, eg, Antonios Tzanakopoulos, Disobeying the Security Council (OUP 2011); Erika de Wet, The Chapter VII Powers of the United Nations Security Council (Hart Publishing 2004); David Schweigman, The Authority of the Security Council Under Chapter VII of the UN Charter (Kluwer 2001).

52 See Daniel H Joyner, 'The Security Council as a Legal Hegemon' (2012) 43 Georgetown J Intl L 225.

53 See UNGA Res 66/186 (22 December 2011) on unilateral economic measures as a means of political and economic coercion against developing countries. 
to certain rights of states should be understood, interpreted, and applied. This is why we have conceived of this special issue as consisting of two sections.

Section one addresses the first, ontological perspective, and may generally be described as setting the historical, theoretical and doctrinal framework for understanding the doctrine of the fundamental rights of states in international law. The first paper will be by Stephen Neff, and considers the history of the concept of the doctrine, stretching back through the classical period of international law, and forward through the midtwentieth century. This is followed by two papers by Jean d'Aspremont and Helmut Philipp Aust. In these papers the authors consider the theoretical underpinnings of the concept of the fundamental rights of states in international law.

In section one, the contributors consider in their respective chapters the following questions:

1. What is the juridical nature of the concept of fundamental rights of states in international law? Is the idea of fundamental rights of states linked to a particular approach to international law, theoretical or otherwise?

2. Do fundamental rights of states constitute a positively ascertainable and distinct normative category, or are they better described as a method of argumentation and delimitation of the scope of corresponding obligations of others, or in some other manner?

3. What is or what should be considered to be the origin/legal basis of fundamental rights of states within the theory of sources?

4. Is there some kinship between the concept of fundamental rights of states and the jus cogens quality of some rules in international law? Or is there a better and distinct way to understand why some rights of states are asserted in legal sources to have qualities including inalienability, inherency or permanency? Could it be claimed, for instance, that they are a corollary of statehood? If so, do such rights of states give content to statehood, or are they rather the consequence thereof?

This macro view of the evolution of the concept of fundamental rights of states can provide important insight into how existing positive law sources should be understood, interpreted and applied.

The six papers comprising section two of the special issue will address a series of case studies of certain rights of states to which positive law attaches special characteristics. The section two authors have researched the discrete asserted right assigned to them and have considered, among other questions:

1. Whether indeed it can be concluded that such a right has a fundamental character and, if so, in what sense;

2. Whether attributes like inherency, inalienability and permanency have legal implications or are only part of the textual package which manifests a narrative of resistance and revindication; 
3. What international legal obligations, if any, the right potentially or actually comes into conflict with, and what the understood outcome of this conflict should be.

The six asserted state rights to be considered in section two are:

1. The right to existence (author: Jure Vidmar);

2. The right to non-intervention/non-interference (author: Niki Aloupi);

3. The right to permanent sovereignty over natural resources (author: Yogesh Tyagi);

4. The right to be free from economic coercion (author: Antonios Tzanakopoulos);

5. The right to self-defence (author: Marco Roscini); and

6. The right to the peaceful use of nuclear energy (author: Daniel H Joyner).

It is our hope that the papers in this special issue will provide some clarity concerning the existence, character, meaning and implications of a number of important, asserted rights of states in international law. We further hope that this effort will be the beginning of a more general renaissance of scholarly and practical attention to this long-neglected, yet timely and increasingly important, subject. 